\title{
Busca por Tomato yellow leaf curl virus e Tomato yellow leaf curl Sardinia virus em tomateiros
}

\author{
Alice K. Inoue-Nagata ${ }^{1}$; Jesús Navas-Castillo²; Paulo C.T. de Melo ${ }^{3}$; Antônio C. de Ávila ${ }^{1}$ \\ 'Embrapa Hortaliças, C. Postal 218, 70359-970 Brasília-DF; alicenag@ cnph.embrapa.br; ²Estación Experimental "La Mayora”, CSIC, \\ 29750 Algarrobo-Costa, Málaga, Spain; ${ }^{3}$ ESALQ, Depto. Agricultura, 13418-900 Piracicaba-SP
}

\section{RESUMO}

A doença causada pelo complexo de vírus do tomato yellow leaf curl (TYLC) é muito séria em tomateiro, principalmente na América Central e Europa, e é causada por um complexo de begomovírus monopartidos. A doença torna-se predominante, mesmo em áreas com a presença de outros begomovírus. No Brasil, os problemas advindos da infecção por begomovírus figuram entre os principais fatores de perdas e oneração de custos. A introdução do complexo TYLC representa uma grande ameaça para os produtores. Este estudo visou a realização de testes de detecção baseados em reação de polimerase em cadeia (PCR) e hibridização específicos em amostras suspeitas coletadas no estado de São Paulo. Um total de 46 amostras com sintomas lembrando aqueles causados pelo complexo TYLC foram coletados no município de Campinas. Todas as amostras foram negativas para detecção de Tomato yellow leaf curl virus e Tomato yellow leaf curl Sardinia virus, as duas espécies mais importantes do completo TYLC. Este resultado sugeriu que as duas espécies de vírus ainda não foram introduzidas no Brasil ou que ainda não apresentam uma larga distribuição.

Palavras-chave: Lycopersicon esculentum, geminivírus, TYLCV, TYLCSV.

\section{ABSTRACT}

Survey on Tomato yellow leaf curl virus and Tomato yellow leaf curl Sardinia virus in tomatoes

The disease caused by the virus complex of tomato yellow leaf curl (TYLC) is extremely severe in tomato plants, notably in Central America and Europe, and is caused by a complex of begomovirus species. The disease becomes predominant even in areas with the presence of other begomoviruses. In Brazil. the problems arisen from begomovirus infection are one of the major factors for damages and increasing the costs. The introduction of the TYLC complex implies in a great threat for growers. This study aimed to carry out detection tests based on PCR (polymerase chain reaction) and specific hybridization on suspected samples collected in the São Paulo State, Brazil. A total of 46 samples with symptoms resembling those caused by the TYLC complex were collected in Campinas county. All samples were negative for the detection of Tomato yellow leaf curl virus and Tomato yellow leaf curl Sardinia virus, the two most important virus from the TYLC complex. This result suggested that the two species have not yet been introduced in Brazil or that they are not widespread.

Keywords: Lycopersicon esculentum, geminivirus, TYLCV, TYLCSV.

(Recebido para publicação em 26 de abril de 2004 e aceito em 6 de setembro de 2004)

A doença do tomato yellow leaf curl (TYLC) é devastadora em regiões tropicais e subtropicais (Polston et al., 1999) do mundo e é causada por um complexo de vírus do gênero Begomovirus (família Geminiviridae). Os sintomas da doença consistem de enrolamento para cima das margens dos folíolos, redução da área foliar, amarelecimento dos folíolos, abortamento de flores e enfezamento da planta (Figura 1). Dentre as oito espécies do complexo TYLC, o Tomato yellow leaf curl Sardinia virus (TYLCSV) e Tomato yellow leaf curl virus (TYLCV, anteriormente conhecido como TYLCVIs, Figura 1) são as espécies mais disseminadas no mundo (Czosnec e Laterrot, 1997; Navas-Castillo et al., 1997; 1999). Os sintomas causados por estas duas espécies e pelas demais do complexo TYLC são semelhantes entre si e a diferenciação não pode ser feita pela sintomatologia. As duas espécies são monopartidas, ou seja são constituídas por apenas um único tipo de DNA na sua composição genômica. Os begomovírus bipartidos são constituídos por duas espécies de DNA, denominados A e B, e estão largamente disseminados em tomateiros no Brasil (Ambrozevicius et al., 2002; Ribeiro et al., 2003).

Na América Central, após a introdução do TYLCV este vírus tornou-se predominante e responsável por imensas perdas em tomateiro, mesmo com a presença anterior das espécies bipartidas (Maxwell, 2002). Visando verificar a possível ocorrência dessas duas espécies de vírus no estado de São Paulo, uma busca por begomovírus monopartidos das espécies TYLCSV e TYLCV foi feita em sete campos em municípios produtores de tomate próximos à cidade de Campinas, uma grande região produtora de tomate de mesa. Quarenta e seis amostras mostrando sintomas muito similares aos causados pelo complexo TYLC (amarelecimento e enrolamento severo de folhas e epinastia) foram cuidadosamente selecionadas e verificada a presença de begomovírus via testes moleculares: hibridização de DNA e reação de polimerase em cadeia (PCR).

Todas as plantas foram avaliadas por hibridização utilizando três sondas separadamente. A primeira sonda, marcada radioativamente (Ready to go, Amersham Biosciences), foi constituída de fragmentos de DNA de begomovírus bipartidos, incluindo a região amino-terminal do gene da proteína rep, a região intergênica completa e a porção amino-terminal da capa protéica. A segunda sonda foi dirigida para a região intergênica de TYLCV, e a terceira sonda para a região intergênica de TYLCSV. Ambas as sondas para 


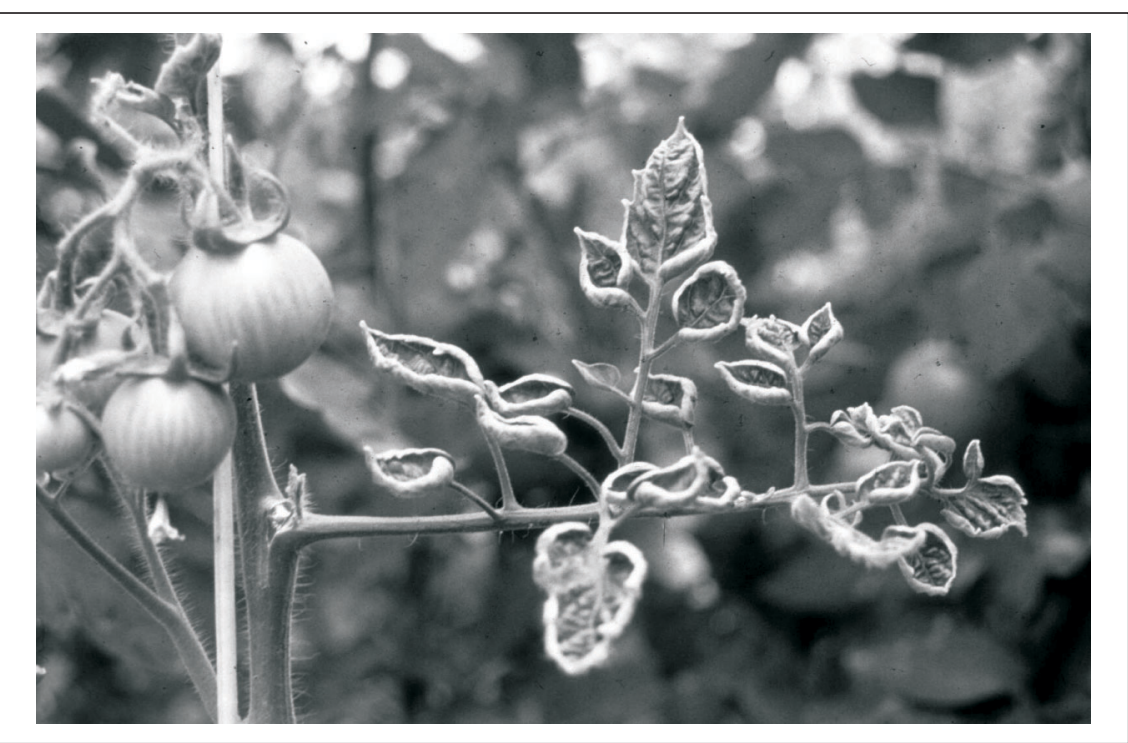

Figura 1. Tomateiro infectado com Tomato yellow leaf curl virus (TYLCV) mostrando enrolamento para cima das margens dos folíolos e redução da área foliar. Espanha, CSCI, 2004.

TYLC foram marcadas com digoxigenina (DIG-dUTP, Roche) e visualizadas por quimioluminescência (ECL, Amersham Biosciences).

Exceto os controles positivos que mostraram reação esperada, nenhuma das 46 amostras coletadas em São Paulo reagiu positivamente com as sondas específicas para TYLCV e TYLCSV. Vinte e sete das 46 amostras e os controles positivos de TYLCV e TYLCSV reagiram positivamente com a sonda de begomovírus bipartido. Estes resultados mostraram que as sondas utilizadas para as espécies bipartidas detectaram ambos os begomovírus monopartidos e bipartidos e que as sondas para vírus monopartidos foram específicas.

Com a finalidade de confirmar os resultados obtidos por hibridização, sete amostras de folhas (quatro positivas e três negativas) foram selecionadas e avaliadas pela técnica de PCR. A PCR foi conduzida com extração total de DNA utilizando oligonucleotídeos específicos para a região intergênica (NavasCastillo et al., 1999) de TYLCV e TYLCSV e para a região conservada da capa protéica de geminivírus (Accotto et al., 2000). Os resultados mostraram que somente os controles positivos de TYLCV e TYLCSV (plasmídeos não infectivos contendo o genoma de cada vírus) resultaram em amplificação de produto específico da PCR utilizando os oligonucleotídeos para a região intergênica de ambas as espécies de
TYLC. Quando a região da capa protéica foi o alvo na PCR, as quatro amostras foram positivas resultando na amplificação esperada. As restantes três amostras de folhas não reagiram positivamente tanto na hibridização como na PCR. Os begomovírus bipartidos e as duas espécies de TYLCV reagiram positivamente por este método indicando que os oligonucleotídeos direcionadas à capa protéica podem ser usados para amplificar ambos os begomovírus mono e bipartidos.

Os resultados obtidos indicam que as espécies TYLCV e TYLCSV não estavam presentes em plantas de tomate com sintomas semelhantes aos causados por esses vírus em outros países. Apesar do levantamento ter sido restrito somente aos municípios produtores de tomate circunvizinhos à cidade de Campinas, os resultados sugerem que os sintomas do tipo TYLC em tomate não são indicativos da presença dessas espécies de begomovírus nas nossas condições. Os oligonucleotídeos específicos para a região intergênica de TYLCV e TYLCSV em nenhuma amostra exceto para os controles positivos amplificaram fragmentos de DNA esperados. Porém, quando oligonucleotídeos eram direcionados à capa protéica na $\mathrm{PCR}$, os isolados bipartidos e monopartidos das duas espécies puderam ser amplificados.

Os resultados aqui apresentados fortemente sugerem que as espécies TYLCV e TYLCSV são pragas exóticas no Brasil e que a metodologia utili- zando sondas ou mesmo a PCR são adequadas para determinar a presença desses vírus. Um grande esforço deve ser empreendido no sentido de se evitar a entrada de mudas ou moscas-brancas infectadas e constantemente monitorar a introdução desta doença. Neste sentido, a Embrapa Hortaliças está preparada para avaliar os materiais suspeitos. A descoberta de um foco da doença em área ainda restrita pode permitir a erradicação do patógeno e evitar a sua disseminação incontrolável da doença.

\section{AGRADECIMENTOS}

Parte dessa pesquisa recebeu suporte financeiro do $\mathrm{CNPq}$ (projeto bilateral Brasil/CNPq e Espanha/CSIC). Somos também agradecidos ao técnico de laboratório Sr .Élcio Vieira da Silva Lopes pela sua assistência técnica.

\section{LITERATURA CITADA}

ACCOTTO, G.P.; NAVAS-CASTILLO, J.; NORIS, E.; MORIONES, E.; LOURO, D. Typing of tomato yellow leaf curl viruses in Europe. European Journal of Plant Pathology v.106, p.179-86, 2000

AMBROZEVICIUS, L.P.; CALEGARIO, R.F.; FONTES, E.P.B.; CARVALHO, M.G.; ZERBINI, F.M. Genetic diversity of begomoviruses infecting tomato and associated weeds in Southeastern Brazil. Fitopatologia Brasileira, Brasília, v.27, p.372-377, 2002.

CZOSNEK, H.; LATERROT, H. A worldwide survey of tomato yellow leaf curl viruses. Arch. Virol. v.142, p.1391-1406, 1997.

MAXWELL, D. Molecular characterization of tomato-infecting Geminiviruses in Central America. Update on Dominican Republic story. Hirt. and Crop Science Series v.724, p.4, 2002. NAVAS-CASTILLO, J.; SÁNCHEZ-CAMPOS, S.; DÍAZ, J.A.; SÁEZ-ALONSO, E.; MORIONES, E. First report of tomato yellow leaf curl virus-Is in Spain: coexistence of two different geminiviruses in the same epidemic outbreak. Plant Dis. v.81, p.1461, 1997.

NAVAS-CASTILLO, J.; SÁNCHEZ-CAMPOS, S.; DÍAZ, J.A.; SÁEZ-ALONSO, E.; MORIONES, E. Tomato yellow leaf curl virus-Is causes a novel disease of common bean and severe epidemics in tomato in Spain. Plant Disease, v.83, p.29-32, 1999.

POLSTON, J.E.; MCGOVERN, R.J.; BROWN, L.G. Introduction of tomato yellow leaf curl virus in Florida and implications for the spread of this and other geminiviruses of tomato. Plant Disease, v.83, p.984-988, 1999.

RIBEIRO, S.G.; AMBROZEVICIUS, L.P.; ÁVILA, A.C.; CALEGARIO, R.F.; FERNANDES, J.J.; LIMA, M.F.; MELLO, R.N.; ROCHA, H.; ZERBINI, F.M. Distribution and genetic diversity of tomato-infecting begomoviruses in Brazil. Arch. Virol., v.148, p.281-295, 2003. 